\title{
First Total Synthesis and Assignment of the
}

\section{Stereochemistry of Crispatenine}

Julien Bourdron, ${ }^{a}$ Laurent Commeiras, ${ }^{a *}$ Gérard Audran, ${ }^{b}$ Nicolas Vanthuyne, ${ }^{b}$ J. C. Hubaud and Jean-Luc Parrain ${ }^{a^{*}}$

${ }^{a}$ UMR-CNRS 6178 SymBio, équipe Synthèse par voie Organométallique, Université Paul Cézanne (AixMarseille III), Avenue Escadrille Normandie Niemen, service 532, 13397 Marseille cedex 20, France

${ }^{b}$ UMR 6180 "Chirotechnologies: Catalyse et Biocatalyse" Université Paul Cézanne (Aix-Marseille III), France

${ }^{c}$ DIPTA (SA), zac pichaury 2, 415 rue Pierre Berthier, 13290 Aix-en-Provence, France

laurent.commeiras@univ-cezanne.fr_jl.parrain@univ-cezanne.fr

S2: General Experimental Methods

S3 to S5: synthesis procedures of known compounds $( \pm)-\mathbf{5},( \pm)-\mathbf{4},( \pm)-\mathbf{6},( \pm)-\mathbf{7},( \pm)-\mathbf{8},( \pm)-\mathbf{3}$, S6 to $\mathrm{S} 7:{ }^{1} \mathrm{H}$ spectrum of $\mathbf{5 , 4 , 8 , 3}$

S8 to S18: ${ }^{1} \mathrm{H}$ and ${ }^{13} \mathrm{C}$ NMR spectrums of $14,15,9,9$ ', 10, 11, 2, 1 and iso-1 


\section{General Experimental Methods.}

All reactions sensitive to oxygen and moisture were carried out in oven-dried glassware under a slight positive pressure of argon unless otherwise noted.

${ }^{1} \mathrm{H}$ NMR and ${ }^{13} \mathrm{C}$ NMR spectra were determined on a AC300 or AC500. Chemical shifts for ${ }^{1} \mathrm{H}$ NMR were reported in parts per million (ppm) downfield from tetramethylsilane as the internal standard and coupling constants are in Hertz (Hz). Chemical shifts for ${ }^{13} \mathrm{C} \mathrm{NMR}$ were reported in ppm relative to the central line of a triplet at $77.16 \mathrm{ppm}$ for deuteriochloroform. ${ }^{1} \mathrm{H}$ multiplicity assignments were made based on HMQC and ${ }^{13} \mathrm{C}$ peak based on DEPT data.

Reagents and solvents were commercial grades and were used as supplied. Dichloromethane, benzene, and toluene were distilled from calcium hydride and stored over molecular sieves 4 $\AA$. THF and diethyl ether were distilled from sodium benzophenone prior to use. $N, N$ dimethylformamide was purchased anhydrous and stored over molecular sieves $4 \AA$ under argon.

Mass spectra (MS) were performed with a triple quadrupole system with a pneumatically assisted electrospray interface.

High resolution mass spectra (HRMS) have been performed using a mass spectrometer equipped with a pneumatically assisted atmospheric pressure ionization. The sample was ionized in positive mode electrospray in the following conditions: electrospray voltage (ISV): $5500 \mathrm{~V}$; orifice voltage (OR): $70 \mathrm{~V}$; nebulising gas flow pressure (air): 0.6 psi. The mass spectrum was obtained using a time of flight analyzer (TOF). The measure was realized in triplicate. The sample was dissolved in methanol $(500 \mu \mathrm{L})$ then diluted (dilution factor $4 / 10000)$ in a methanolic solution of ammonium acetate $(3 \mathrm{mM})$. The sample solution was infused in the ionization source at a $5 \mu \mathrm{L} / \mathrm{min}$ flow rate.

The analytical chiral HPLC experiments were performed on a unit composed of a system manager, a pump, an oven, an UV-detector, and an on-line polarimeter. Hexane and 2-PrOH, HPLC grade, were degassed and filtered on a $0.45 \mu \mathrm{m}$ membrane before use. The column used is Whelk-O1 $(\mathrm{S}, \mathrm{S})(250 \times 4.6 \mathrm{~mm})$. Retention times Rt in minutes, retention factors $\mathrm{k}_{\mathrm{i}}=$ $\left(\mathrm{Rt}_{\mathrm{i}}-\mathrm{Rt}_{0}\right) / \mathrm{Rt}_{0}$ and enantioselectivity factor $\alpha=\mathrm{k}_{2} / \mathrm{k}_{1}$ are given. $\mathrm{Rt}_{0}$ was determined by injection of tri-tertio-butyl benzene. The sign given by the on-line polarimeter is the sign of the product in the solvent used for the chromatographic separation. The analyses were performed at $25^{\circ} \mathrm{C}$, with hexane/2-PrOH (95/5) as mobile phase and $1 \mathrm{~mL} / \mathrm{min}$ as flow-rate, with UV at $220 \mathrm{~nm}$ and polarimeter. $1: \mathrm{Rt}_{1}(+)=10.74, \mathrm{Rt}_{2}(-)=11.49, \mathrm{k}_{1}(+)=2.70, \mathrm{k}_{2}(-)=2.96, \alpha=1.10$. Iso-1 $\mathrm{Rt}_{1}(-)=8.64, \mathrm{Rt}_{2}(+)=10.42, \mathrm{k}_{1}(-)=2.05, \mathrm{k}_{2}(+)=2.59, \alpha=1.27$. Semi-preparative separations were performed by successive injections on an unit composed of a pump, a autosampler, an UV-detector and a valve to collect separately the different isomers. First, Whelk-O1 (S,S) $(250 \times 10 \mathrm{~mm})$ was used with hexane/2-PrOH (95/5) as mobile phase, 5 $\mathrm{mL} / \mathrm{min}$ as flow-rate and $\mathrm{UV}$ at $220 \mathrm{~nm}$ to collect $\mathrm{C}(-), \mathrm{D}(+)$ and the mixture $\mathrm{D}(-)$ and $\mathrm{C}(+)$. Then, Whelk-O1 $(\mathrm{R}, \mathrm{R})(250 \times 4.6 \mathrm{~mm})$ was used with hexane/2-PrOH $(95 / 5)$ as mobile phase, $1 \mathrm{~mL} / \mathrm{min}$ as flow-rate and $\mathrm{UV}$ at $220 \mathrm{~nm}$ to collect separately $\mathrm{D}(-)$ and $\mathrm{C}(+)$. 
(E)-2-Tributylstannylbut-2-ene-1,4-diol (5). To a THF solution (15 mL) of but-2-yn-1,4diol (2.58 g, $30 \mathrm{mmol})$ and $\mathrm{PdCl}_{2}\left(\mathrm{PPh}_{3}\right)_{2}(420 \mathrm{mg}, 2 \mathrm{~mol} \%)$ was added dropwise a THF solution $(20 \mathrm{~mL})$ of tributyltin hydride $(9.68 \mathrm{~mL}, 36 \mathrm{mmol})$ over a period of $1 \mathrm{~h}$. The originally light yellow solution abruptly turned orange-brown. After stirring over $15 \mathrm{mn}$, THF was evaporated under vacuum. The crude product was then purified by flash chromatography (light petroleum- $\mathrm{Et}_{2} \mathrm{O}, 6 / 4$ to $2 / 8$ ) to give 5 in $99 \%$ yield. ${ }^{1} \mathrm{H}$ NMR $\left(300 \mathrm{MHz}, \mathrm{CDCl}_{3}\right) \delta$ 0.86-0.95 (m, 15H, $\left.3 \times \mathrm{CH}_{3}, 3 \times \mathrm{CH}_{2}\right), 1.25-1.37\left(\mathrm{~m}, 6 \mathrm{H}, 3 \times \mathrm{CH}_{2}\right), 1.44-1.55(\mathrm{~m}, 6 \mathrm{H}, 3 \times$ $\mathrm{CH}_{2}$ ), 1.66 (br t, $\left.1 \mathrm{H}, J=5.6 \mathrm{~Hz}, \mathrm{OH}\right), 1.75$ (br t, $\left.1 \mathrm{H}, J=5.2 \mathrm{~Hz}, \mathrm{OH}\right), 4.20$ (br t, $2 \mathrm{H}, J=5.4$ $\left.\mathrm{Hz}, \mathrm{CH}_{2}\right), 4.38\left(\mathrm{br} \mathrm{d}, 2 \mathrm{H}, J=3.7 \mathrm{~Hz},{ }^{3} J_{\mathrm{Sn}, \mathrm{H}}=37 \mathrm{~Hz}, \mathrm{CH}_{2}\right), 5.79\left(\right.$ br t $, 1 \mathrm{H}, J=5.4 \mathrm{~Hz},{ }^{3} J_{\mathrm{Sn}, \mathrm{H}}=$ $67 \mathrm{~Hz}, \mathrm{CH})$.

(E)-4-tert-Butyldimethylsilyloxy-2-tributylstannyl but-2-en-1-ol (4). To a solution of 5 $(3.8 \mathrm{~g}, 10 \mathrm{mmol})$ in DMF $(100 \mathrm{~mL})$ at $0{ }^{\circ} \mathrm{C}$ was added imidazole $(0.68 \mathrm{~g}, 10 \mathrm{mmol})$ and tertbutyldimethylsilylchloride $(1.5 \mathrm{~g}, 10 \mathrm{mmol})$. The solution was stirred at $0{ }^{\circ} \mathrm{C}$ for $6 \mathrm{~h}$ then crushed ice (2.5 g) was added. The solution was diluted with $\mathrm{Et}_{2} \mathrm{O}(200 \mathrm{~mL})$, washed with saturated aqueous $\mathrm{NH}_{4} \mathrm{Cl}$ solution, dried over $\mathrm{MgSO}_{4}$ and evaporated. The crude product was then purified by flash chromatography (light petroleum-Et $2 \mathrm{O}, 10 / 0$ to $9 / 1$ ) to give 4 in $65 \%$ yield. ${ }^{1} \mathrm{H}$ NMR $\left(300 \mathrm{MHz}, \mathrm{CDCl}_{3}\right) \delta 0.08\left(\mathrm{~s}, 6 \mathrm{H}, 2 \times \mathrm{CH}_{3}\right), 0.86-0.94\left(\mathrm{~m}, 15 \mathrm{H}, 3 \times \mathrm{CH}_{3}, 3 \mathrm{x}\right.$ $\mathrm{CH}_{2}$ ), 0.90 (s, 9H, $\left.3 \times \mathrm{CH}_{3}\right), 1.25-1.55\left(\mathrm{~m}, 12 \mathrm{H}, 6 \times \mathrm{CH}_{2}\right), 1.82$ (br t, $\left.1 \mathrm{H}, J=5.5 \mathrm{~Hz}, \mathrm{OH}\right)$, $4.22\left(\right.$ br d, $\left.2 \mathrm{H}, J=5.4 \mathrm{~Hz},{ }^{4} J_{\mathrm{Sn}, \mathrm{H}}=15 \mathrm{~Hz}, \mathrm{CH}_{2}\right), 4.34\left(\right.$ br d, $2 \mathrm{H}, J=5.5 \mathrm{~Hz},{ }^{3} J_{\mathrm{Sn}, \mathrm{H}}=37 \mathrm{~Hz}$, $\mathrm{CH}_{2}$ ), 5.70 (br t, $\left.1 \mathrm{H}, J=5.4 \mathrm{~Hz},{ }^{3} J_{\mathrm{Sn}, \mathrm{H}}=69 \mathrm{~Hz}, \mathrm{CH}\right)$.

(3,3-Dimethyl-cyclohex-1-enyl)-methanol (8). To a stirred suspension of $\mathrm{NaH}(11.4 \mathrm{~g}, 0.28$ mol of $60 \%$ mineral oil dispersion) in dry toluene $(265 \mathrm{~mL})$ was added dropwise 2-methyl cyclohexanone $(20 \mathrm{~g}, 0.18 \mathrm{~mol})$ during $2 \mathrm{~h}$ at $100^{\circ} \mathrm{C}$, the mixture being stirred throughout this 
period. To this was added dropwise $\mathrm{MeI}(17.7 \mathrm{~mL}, 0.28 \mathrm{~mol})$ during $2 \mathrm{hr}$ at $60^{\circ} \mathrm{C}$, and the mixture was stirred for a further $2 \mathrm{~h}$ at $60{ }^{\circ} \mathrm{C}$. After cooling, a mixture of NaOMe $(16.3 \mathrm{~g}$, $0.30 \mathrm{~mol})$ and $\mathrm{HCO}_{2} \mathrm{Me}(24.9 \mathrm{~mL}, 0.40 \mathrm{~mol})$ was added to the mixture at $5^{\circ} \mathrm{C}$, and the reaction mixture stirred for a further $12 \mathrm{~h}$ at room temperature before being poured into ice cooled water. The aqueous layer was acidified with $10 \% \mathrm{HCl}$ aq. and extracted with ether. The combined organic phases were washed with brine, dried over $\mathrm{MgSO}_{4}$ and concentrated. The crude product 6 was used without purification.

To a mixture of ethyl vinyl ether $(71 \mathrm{~mL}, 0.74 \mathrm{~mol})$ and $6(21.4 \mathrm{~g}, 0.14 \mathrm{~mol})$ was added $\mathrm{H}_{3} \mathrm{PO}_{4}(0.38 \mathrm{~mL}, 6.5 \mathrm{mmol})$. After stirring for $12 \mathrm{~h}$ at room temperature, the reaction mixture was pourred into saturated aqueous $\mathrm{NaHCO}_{3}$ solution and extracted with ether. The combined organic phases were washed with brine, dried over $\mathrm{MgSO}_{4}$ and concentrated to yield 7 used without purification.

To a stirred suspension of $\mathrm{NaBH}_{4}(4 \mathrm{~g}, 0.11 \mathrm{~mol})$ in $95 \% \mathrm{EtOH}(50 \mathrm{~mL})$ was added dropwise $7(25 \mathrm{~g}, 0.11 \mathrm{~mol})$ during $1 \mathrm{~h}$ at $10^{\circ} \mathrm{C}$. After stirring for $1 \mathrm{~h}, 20 \%$ aq. $\mathrm{H}_{2} \mathrm{SO}_{4}(52.9 \mathrm{~g}, 0.54 \mathrm{~mol})$ was added dropwise to the reaction mixture during $1 \mathrm{~h}$ at room temperature. The mixture was then neutralized with $25 \%$ aqueous $\mathrm{NaOH}$ solution. To the reaction mixture of the crude product was then added $\mathrm{NaBH}_{4}(4 \mathrm{~g}, 0.11 \mathrm{~mol})$ during $30 \mathrm{~min}$ at $10^{\circ} \mathrm{C}$. After stirring for $2 \mathrm{~h}$ at room temperature, the reaction mixture was poured into water and extracted with ether. The combined organic phases were washed with brine, dried over $\mathrm{MgSO}_{4}$ and concentrated. The residue was purified by flash chromatography (light petroleum- $\mathrm{Et}_{2} \mathrm{O}, 9 / 1$ to $1 / 1$ ) to give $\mathbf{8}$ in $36 \%$ yield from 2-methyl cyclohexanone. ${ }^{1} \mathrm{H}$ NMR $\left(\mathrm{CDCl}_{3}, 300 \mathrm{MHz}\right) \delta 0.97(\mathrm{~s}, 6 \mathrm{H}, 2 \mathrm{x}$ $\left.\mathrm{CH}_{3}\right), 1.27(\mathrm{~m}, 1 \mathrm{H}, \mathrm{OH}), 1.39-1.43\left(\mathrm{~m}, 2 \mathrm{H}, \mathrm{CH}_{2}\right), 1.61-1.69\left(\mathrm{~m}, 2 \mathrm{H}, \mathrm{CH}_{2}\right), 1.94$ (br t, $2 \mathrm{H}, J=$ $6.1 \mathrm{~Hz}, \mathrm{CH}_{2}$ ), 3.97 (br s, 2H, $\mathrm{CH}_{2}$ ), 5.39 (s, 1H, CH). 
$\gamma$-Homocyclogeranial (( \pm -3). A mixture of 8 (1.5 g, $10.7 \mathrm{mmol})$, ethyl vinyl ether $(2.1 \mathrm{~mL}$, $11 \mathrm{mmol})$ and pivalic acid $(0.22 \mathrm{~g}, 2.1 \mathrm{mmol})$ was stirred at $220^{\circ} \mathrm{C}$ for $3 \mathrm{~h}$ in an autoclave. After cooling, the reaction mixture was washed with aqueous saturated $\mathrm{NaHCO}_{3}$ solution, dried over $\mathrm{MgSO}_{4}$, and concentrated. The residue was purified by flash chromatography (light petroleum-Et $2 \mathrm{O}, 98 / 2$ to $95 / 5)$ to give and $( \pm)-3$ in $49 \%$ yield. ${ }^{1} \mathrm{H}$ NMR $\left(\mathrm{CDCl}_{3}, 200 \mathrm{MHz}\right) \delta$ $0.78\left(\mathrm{~s}, 3 \mathrm{H}, \mathrm{CH}_{3}\right), 0.98\left(\mathrm{~s}, 3 \mathrm{H}, \mathrm{CH}_{3}\right), 1.25-1.66\left(\mathrm{~m}, 4 \mathrm{H}, 2 \times \mathrm{CH}_{2}\right), 2.0-2.09\left(\mathrm{~m}, 1 \mathrm{H}, \mathrm{CH}_{2}\right)$, 2.15-2.23 (m, $\left.1 \mathrm{H}, \mathrm{CH}_{2}\right), 2.41-2.50\left(\mathrm{~m}, 3 \mathrm{H}, \mathrm{CH}_{2}\right.$ and $\left.\mathrm{CH}\right), 4.52$ (br s, $\left.1 \mathrm{H}, \mathrm{CH}_{2}\right), 4.80$ (br s, $1 \mathrm{H}$, $\left.\mathrm{CH}_{2}\right), 9.64(\mathrm{t}, 1 \mathrm{H}, J=2.2 \mathrm{~Hz}, \mathrm{CH})$. 


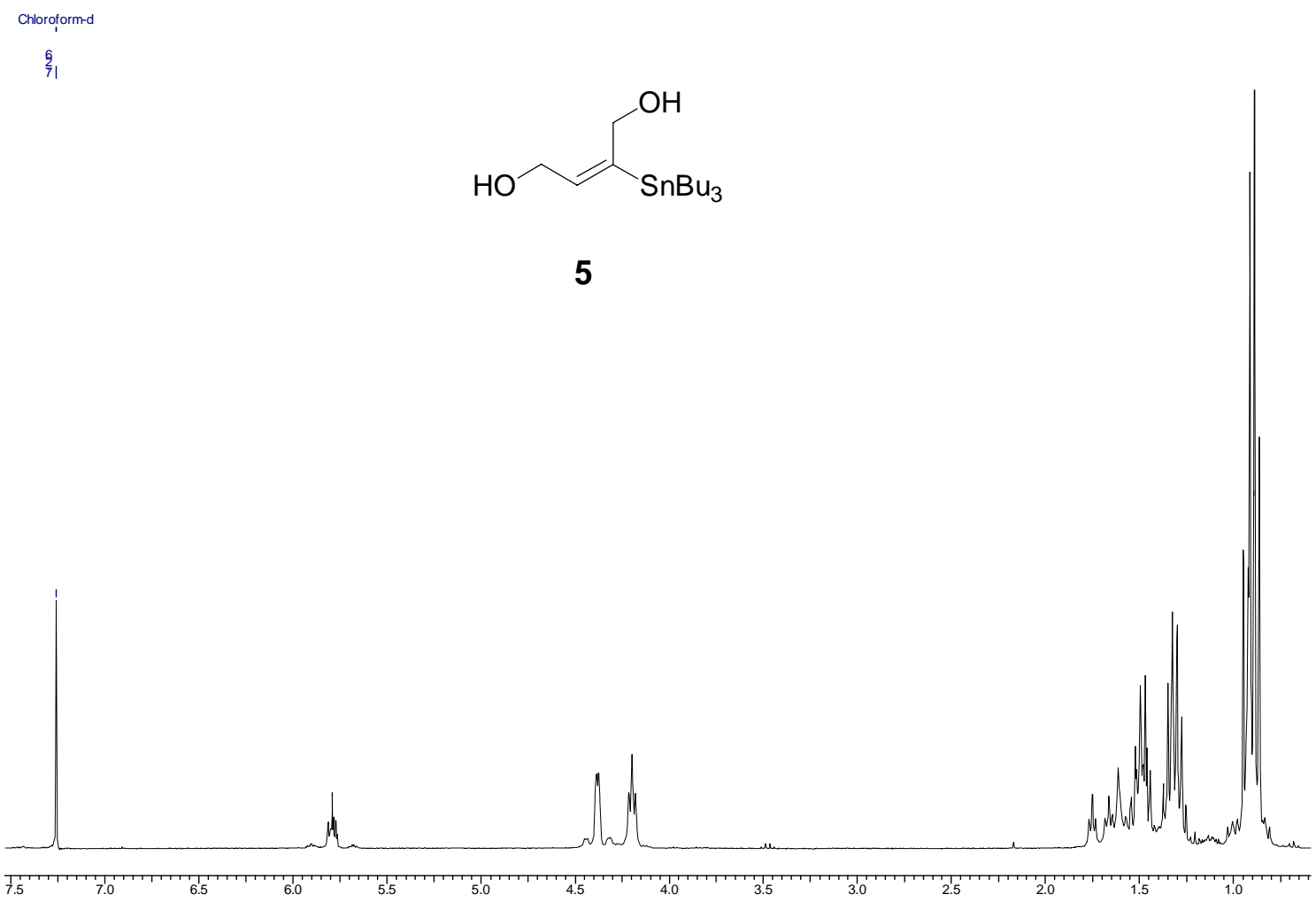

Chloroform-d

₹

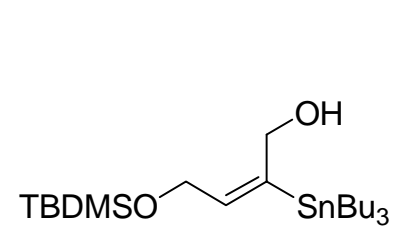

4

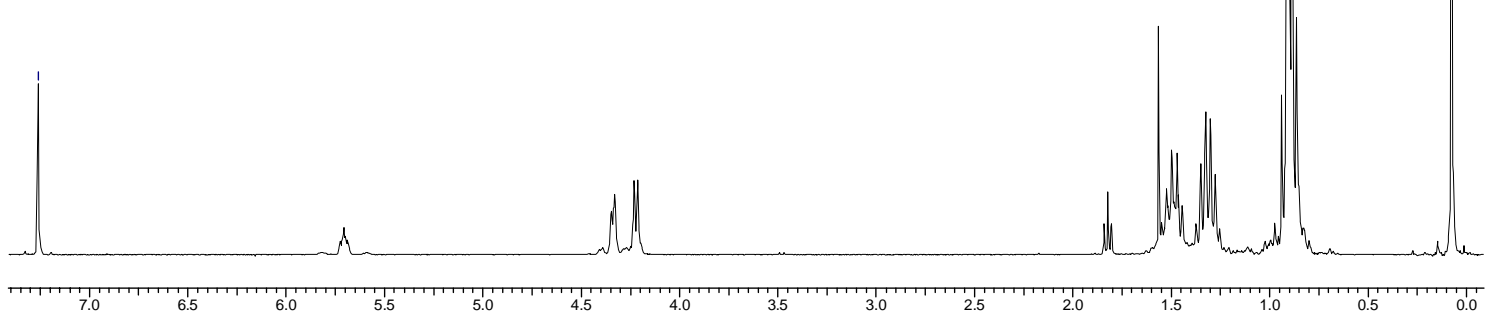

- S6 - 

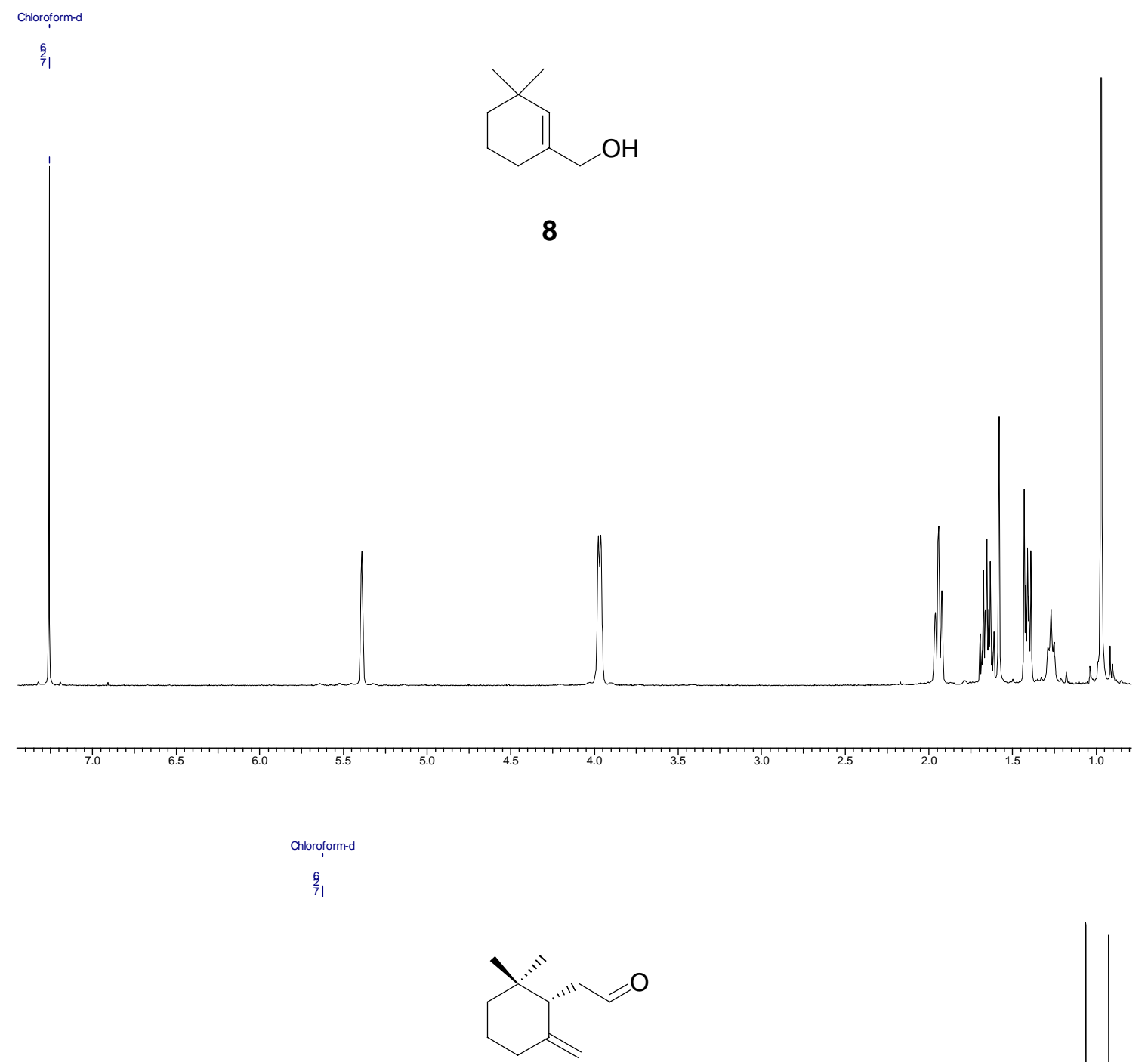

3

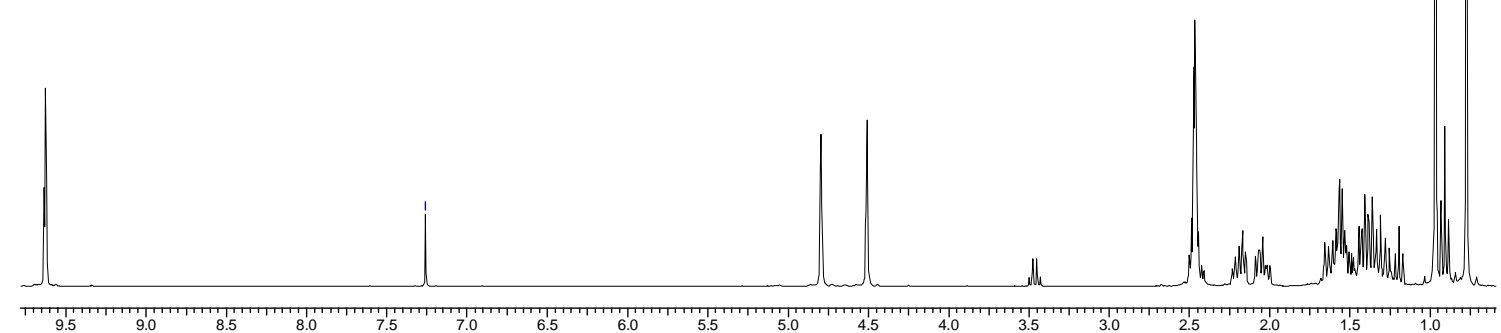

- S7 - 

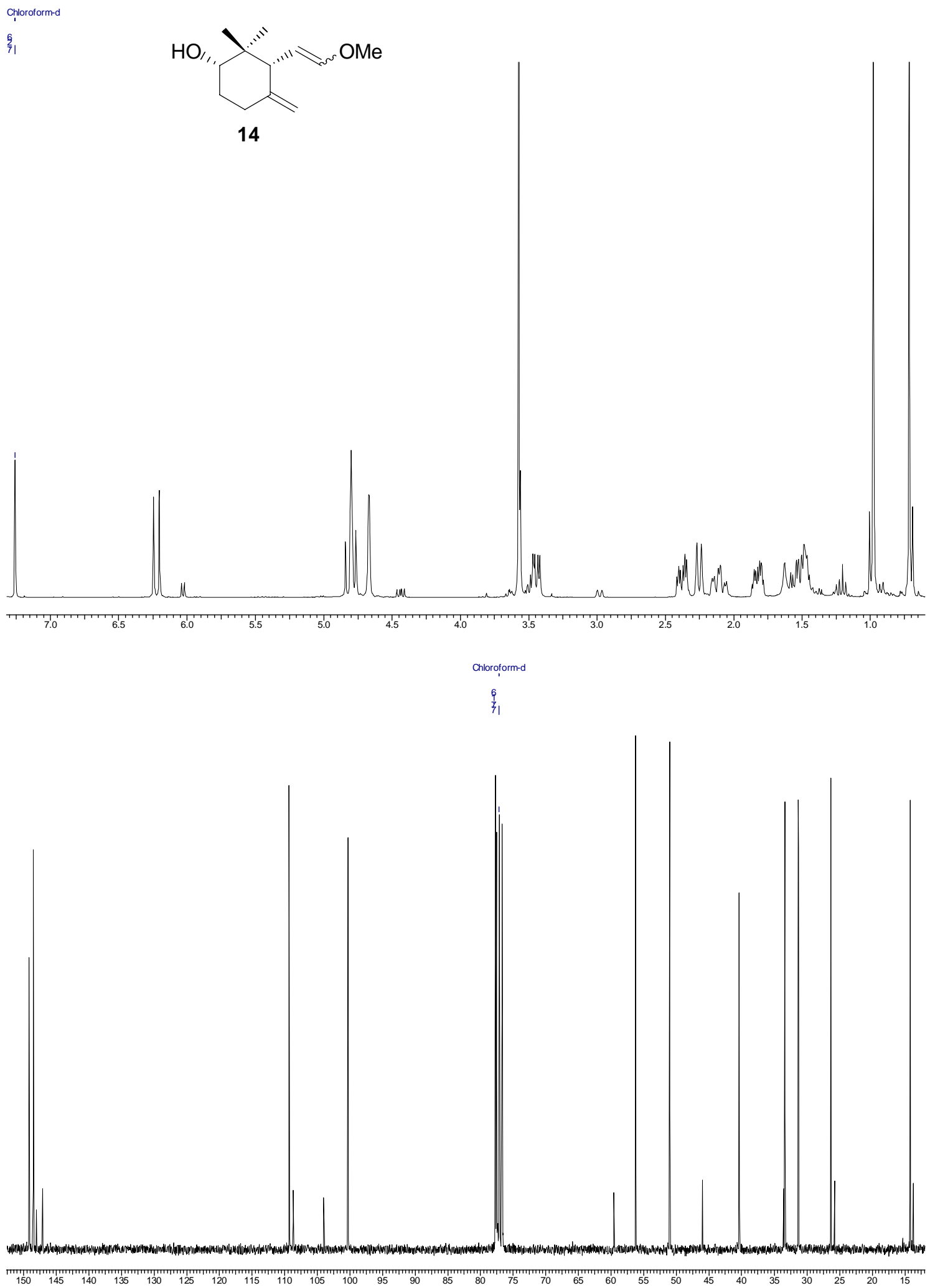

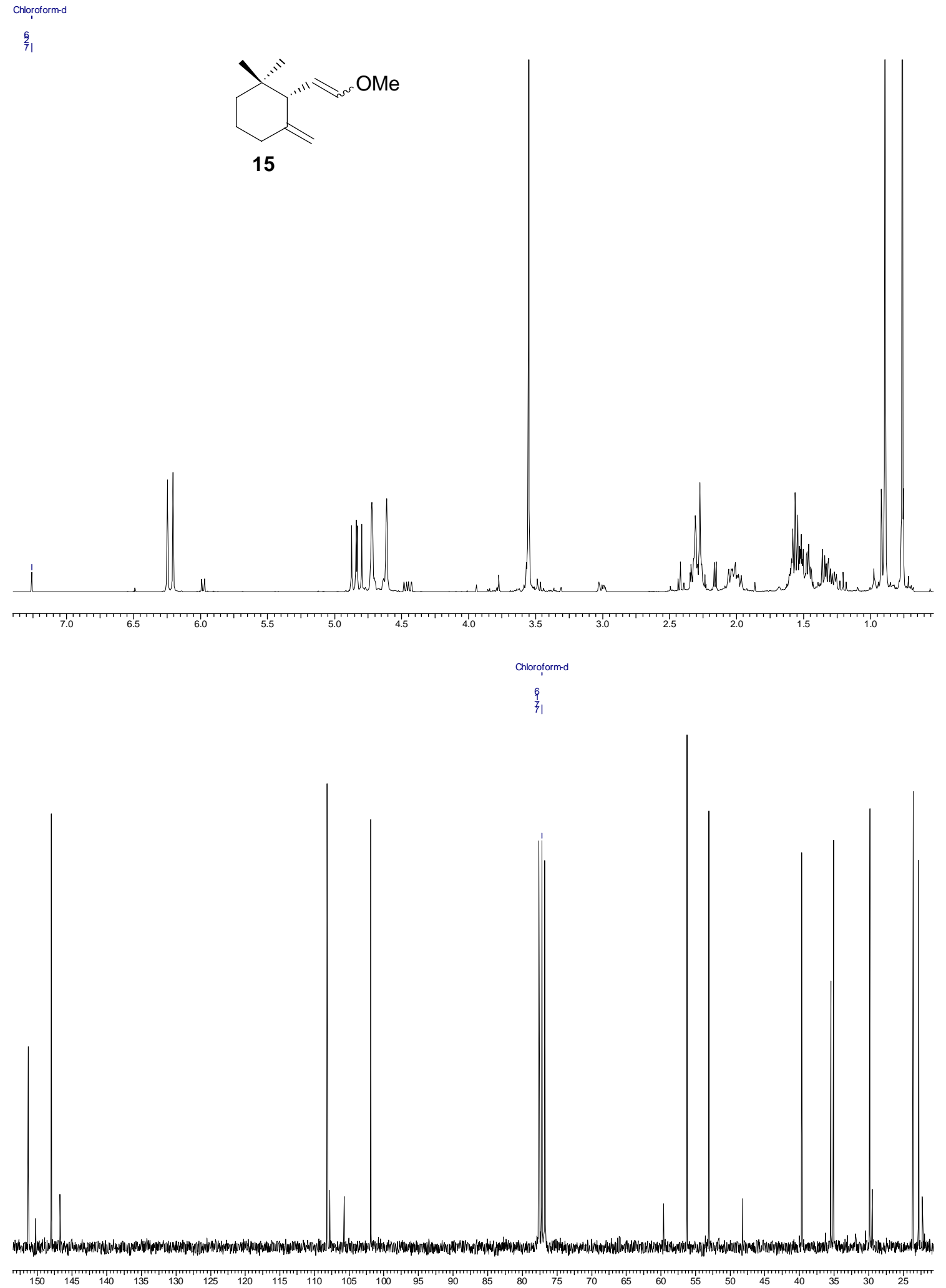

- S9 - 
Chloroform-d

臬<smiles></smiles>
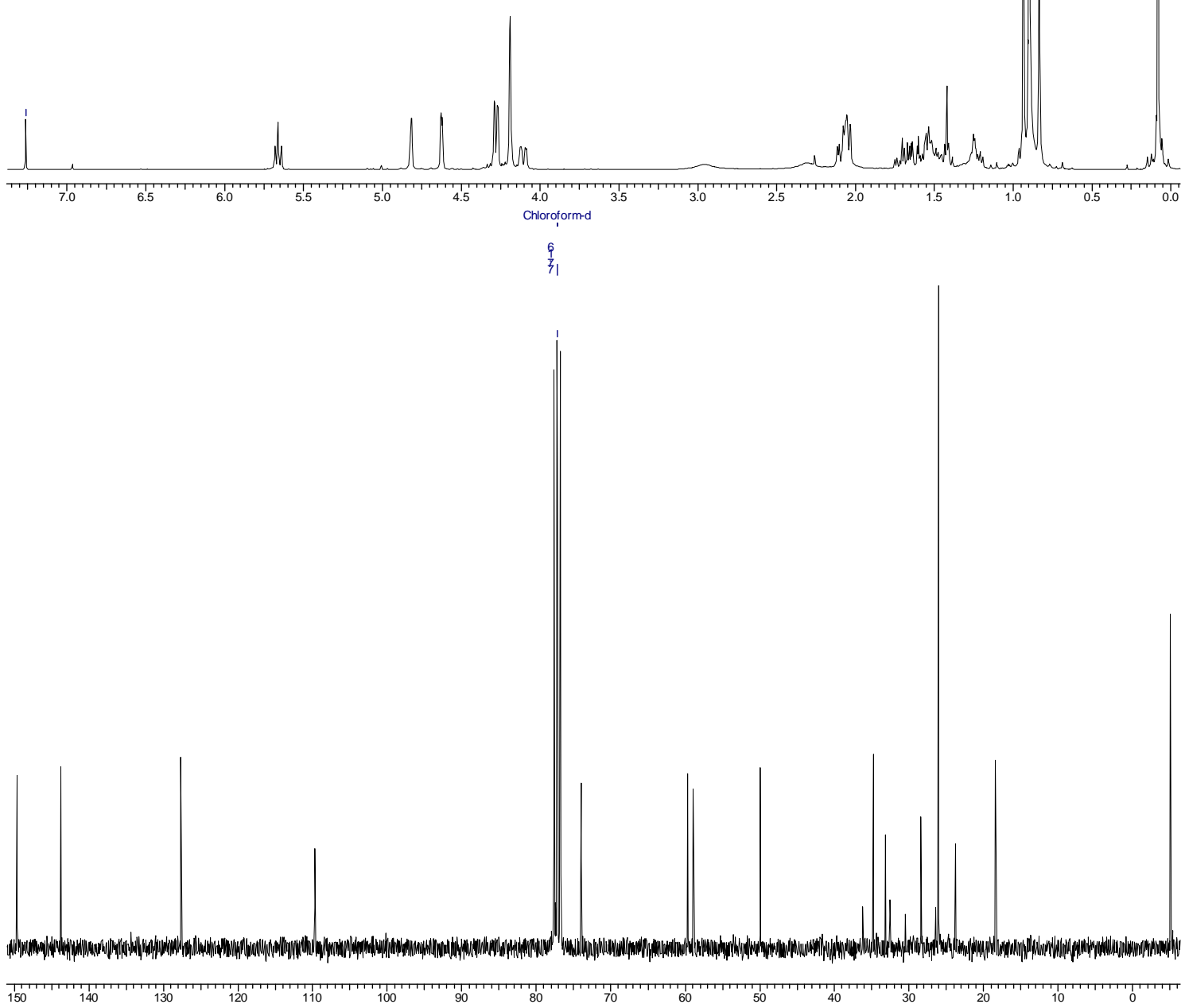
Chloroform-d

鼻
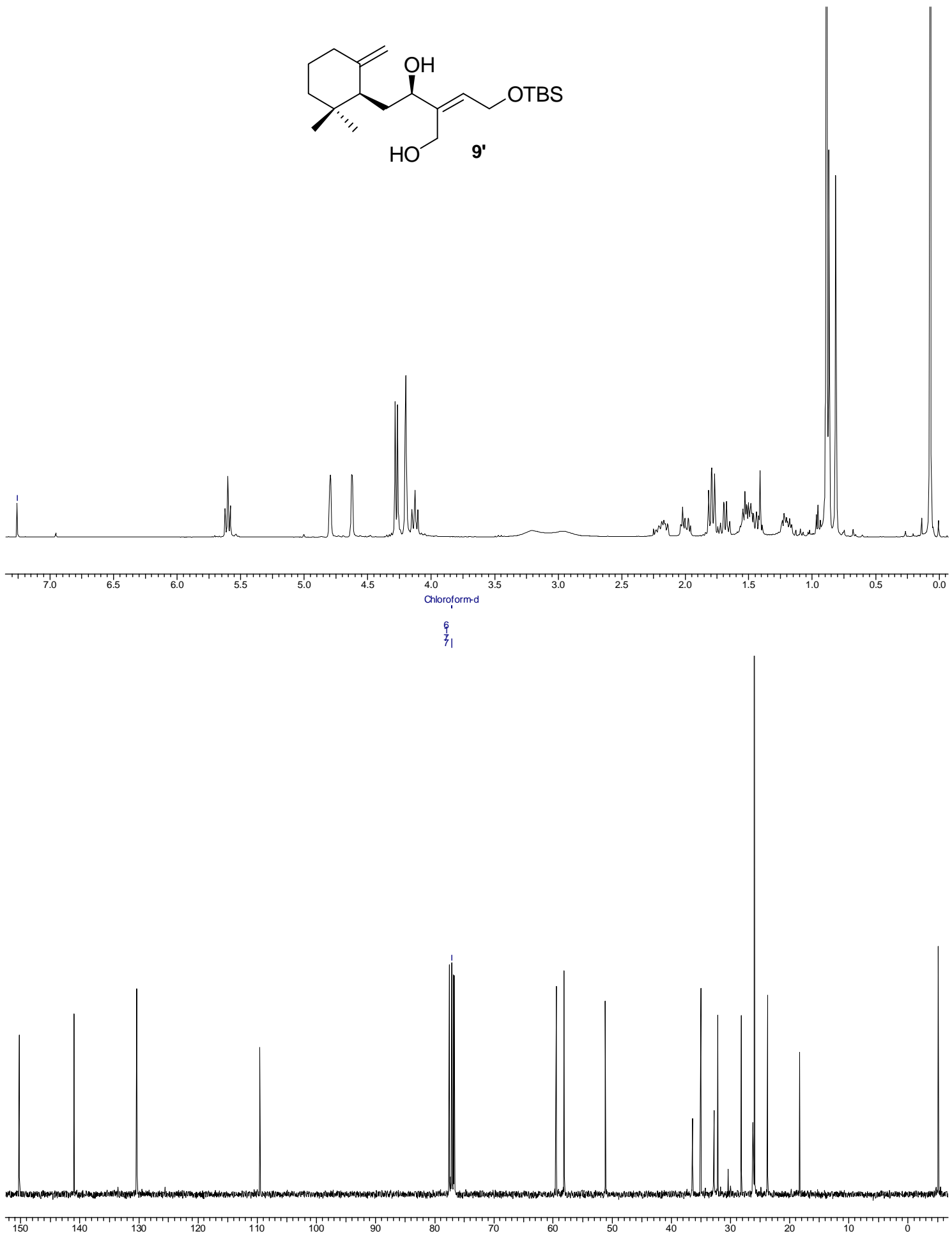
Chloroform-d

臭
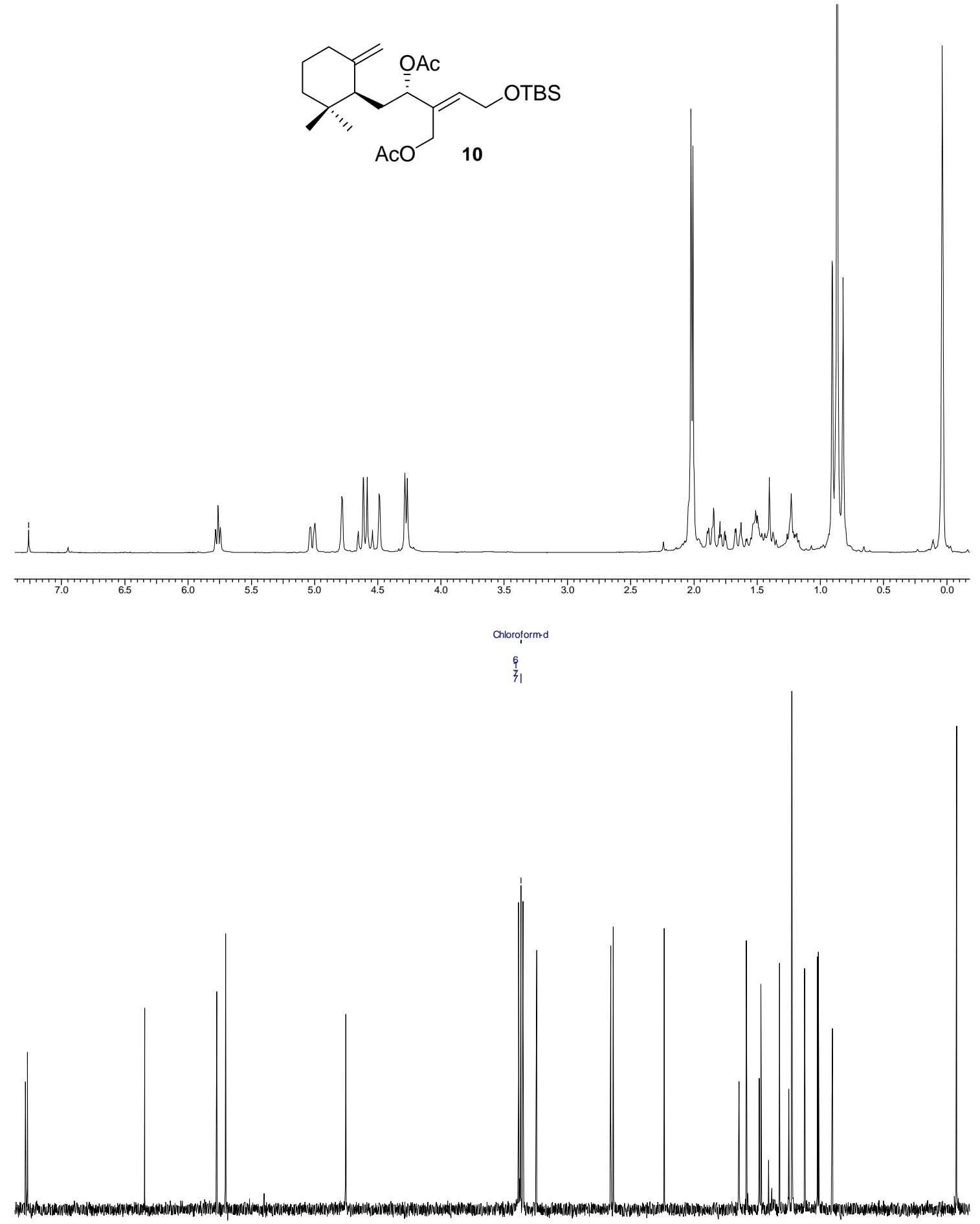

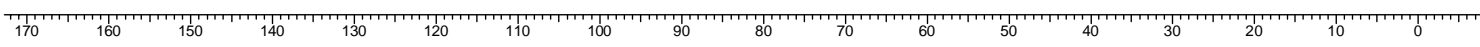


Chloroform-d

臬
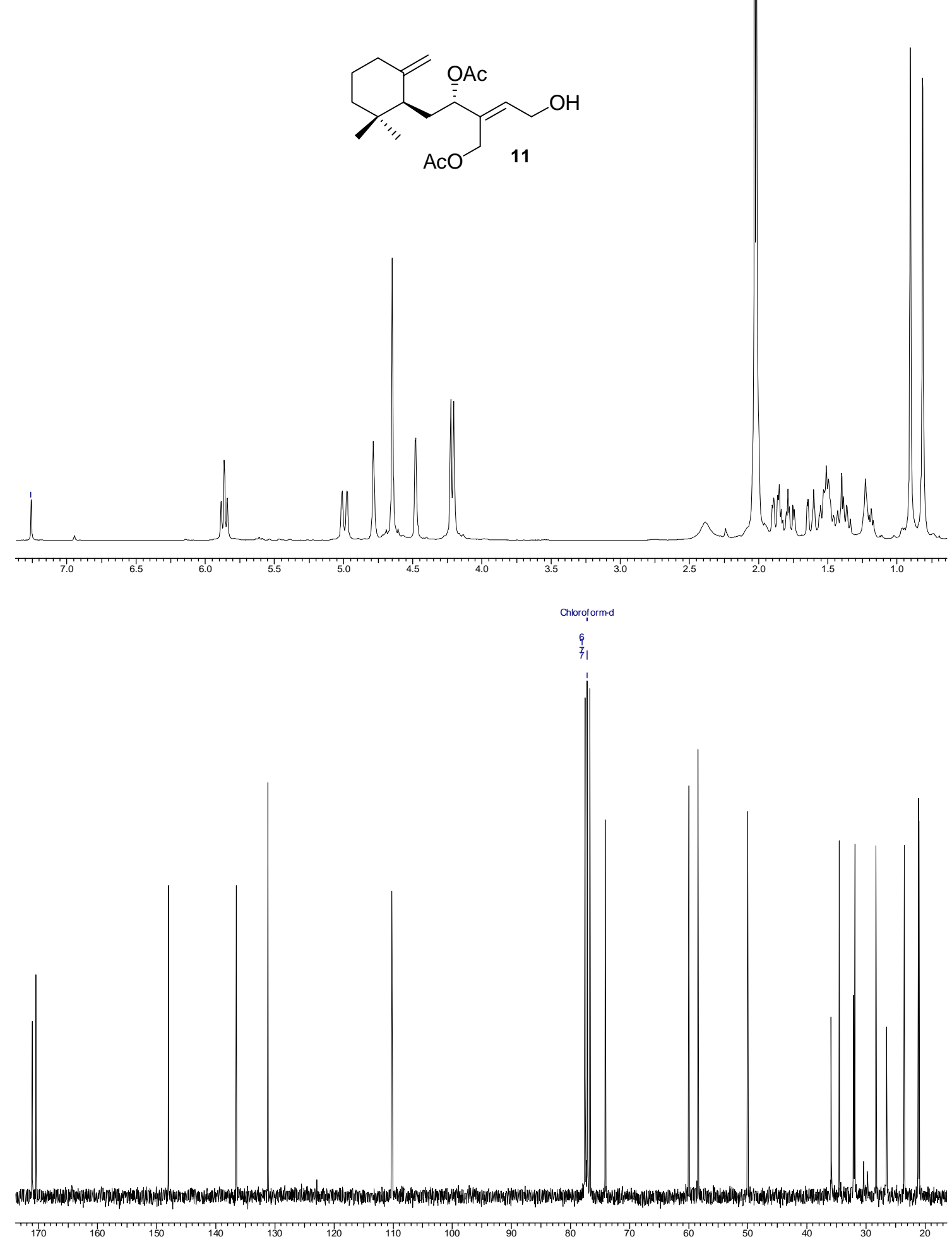

- S13 - 


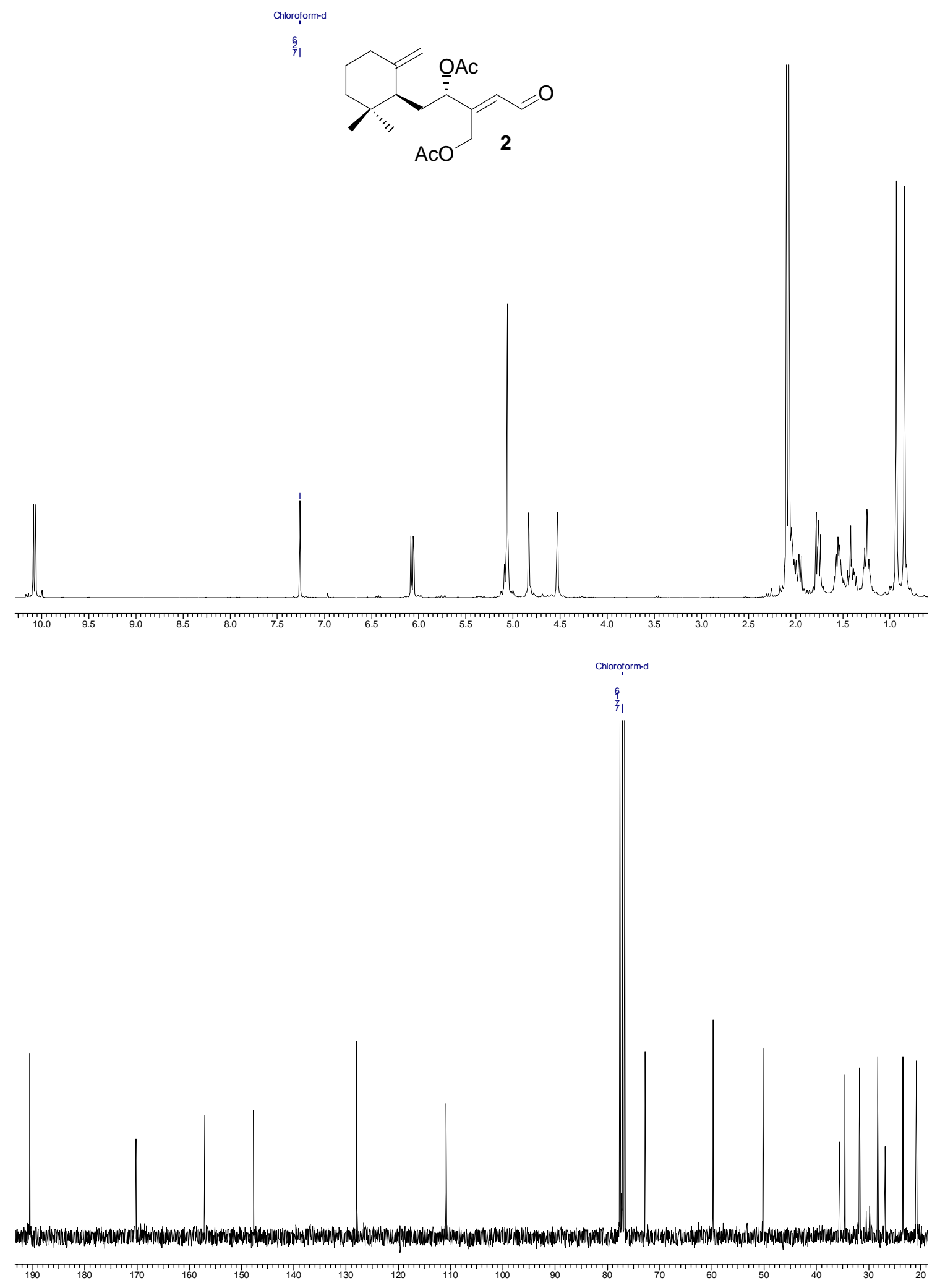


Chloroform-d

鼻

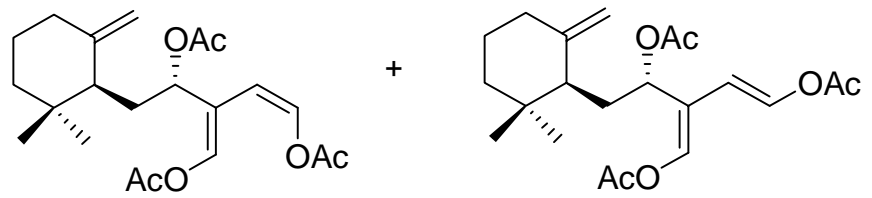

iso-1

1

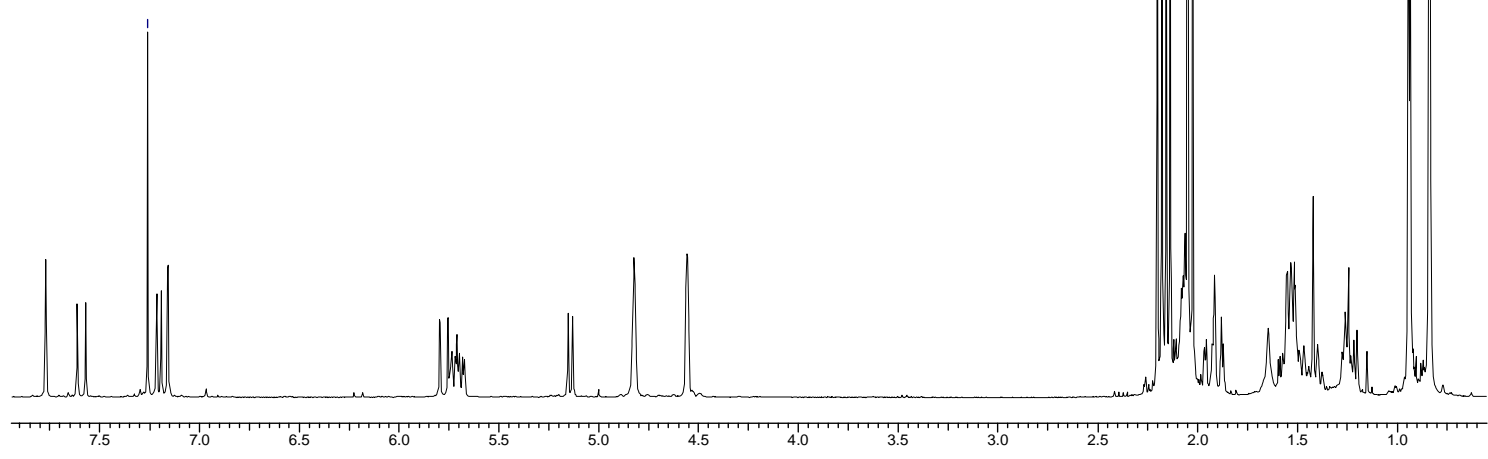




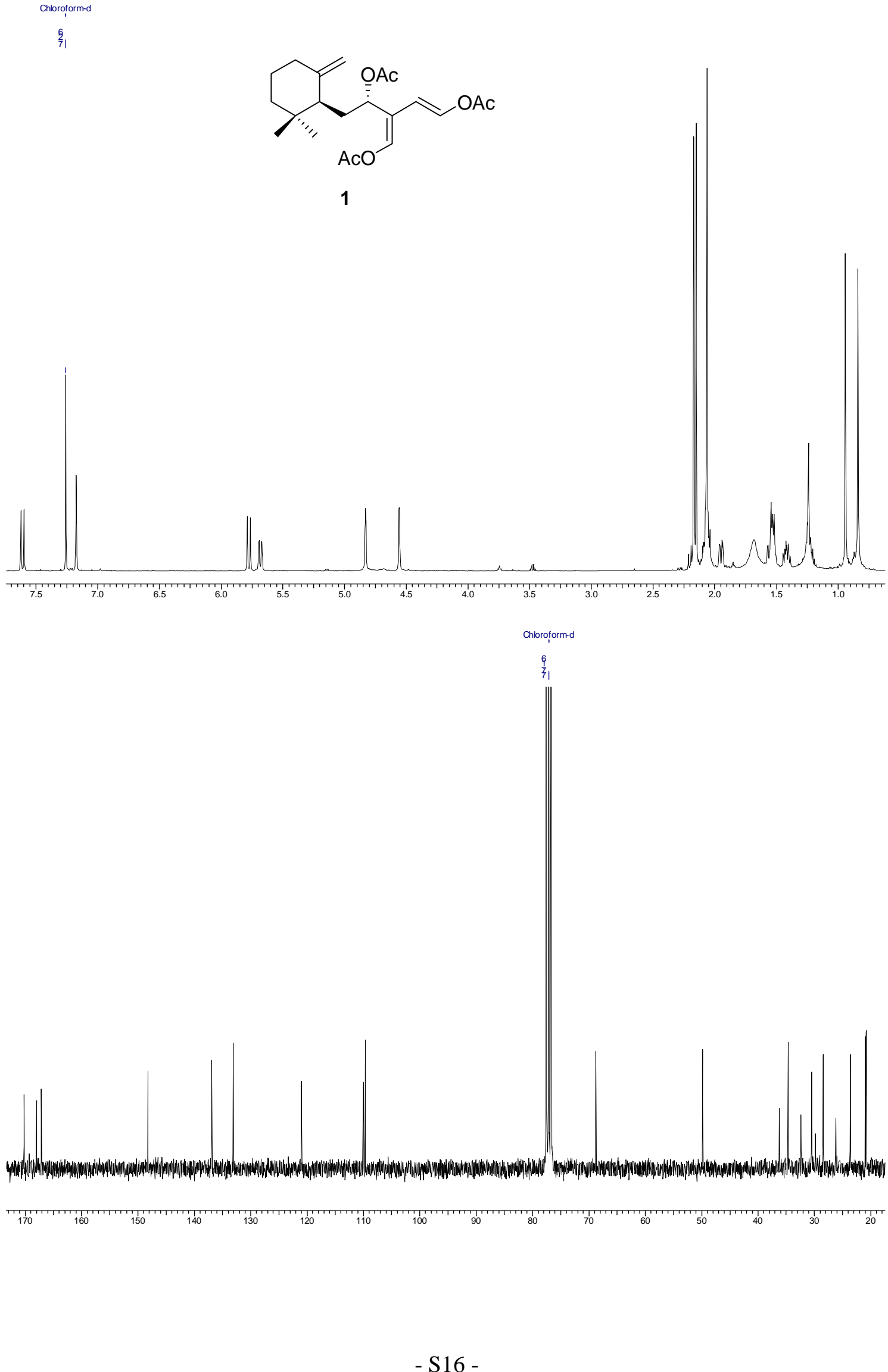



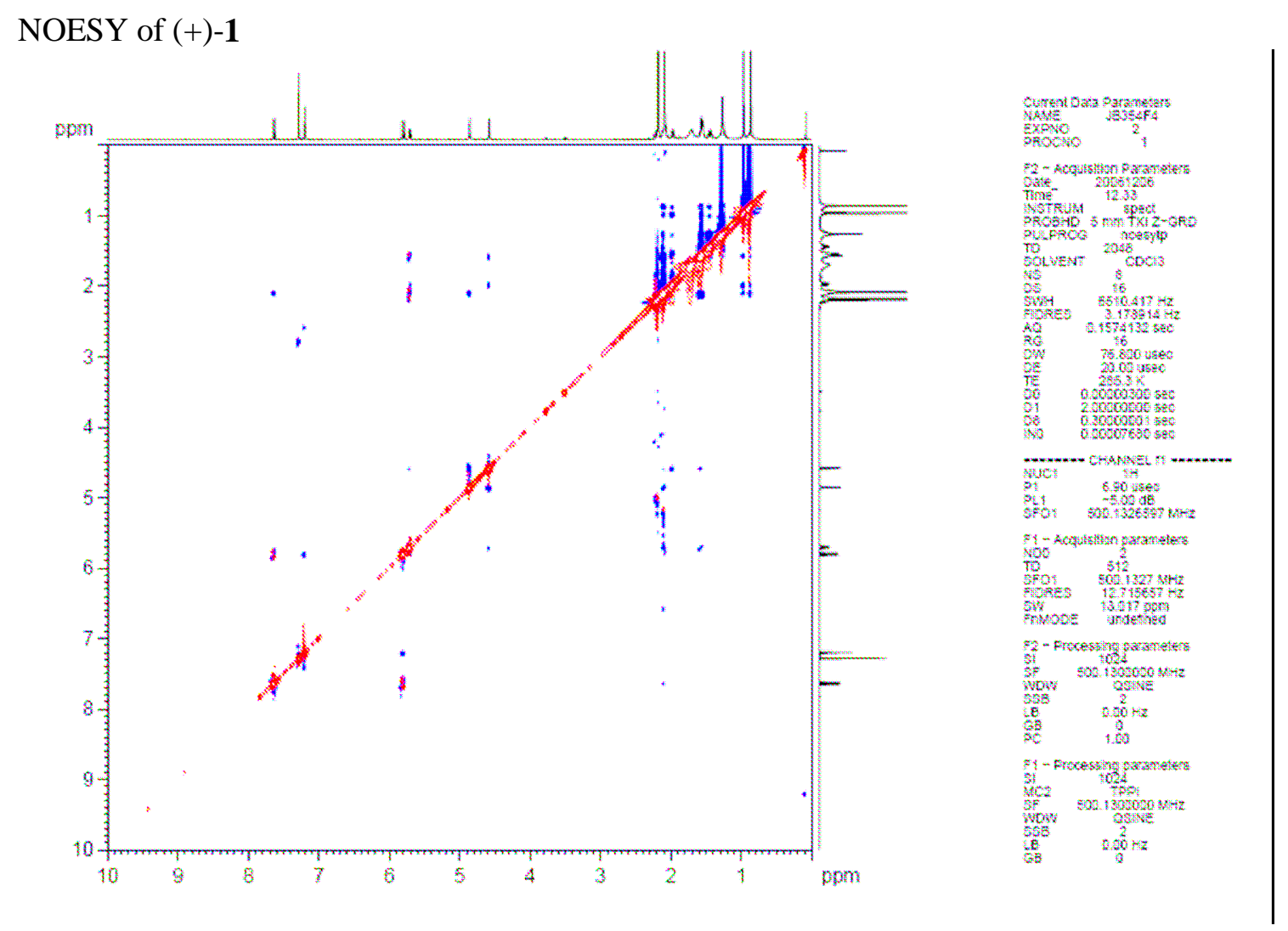

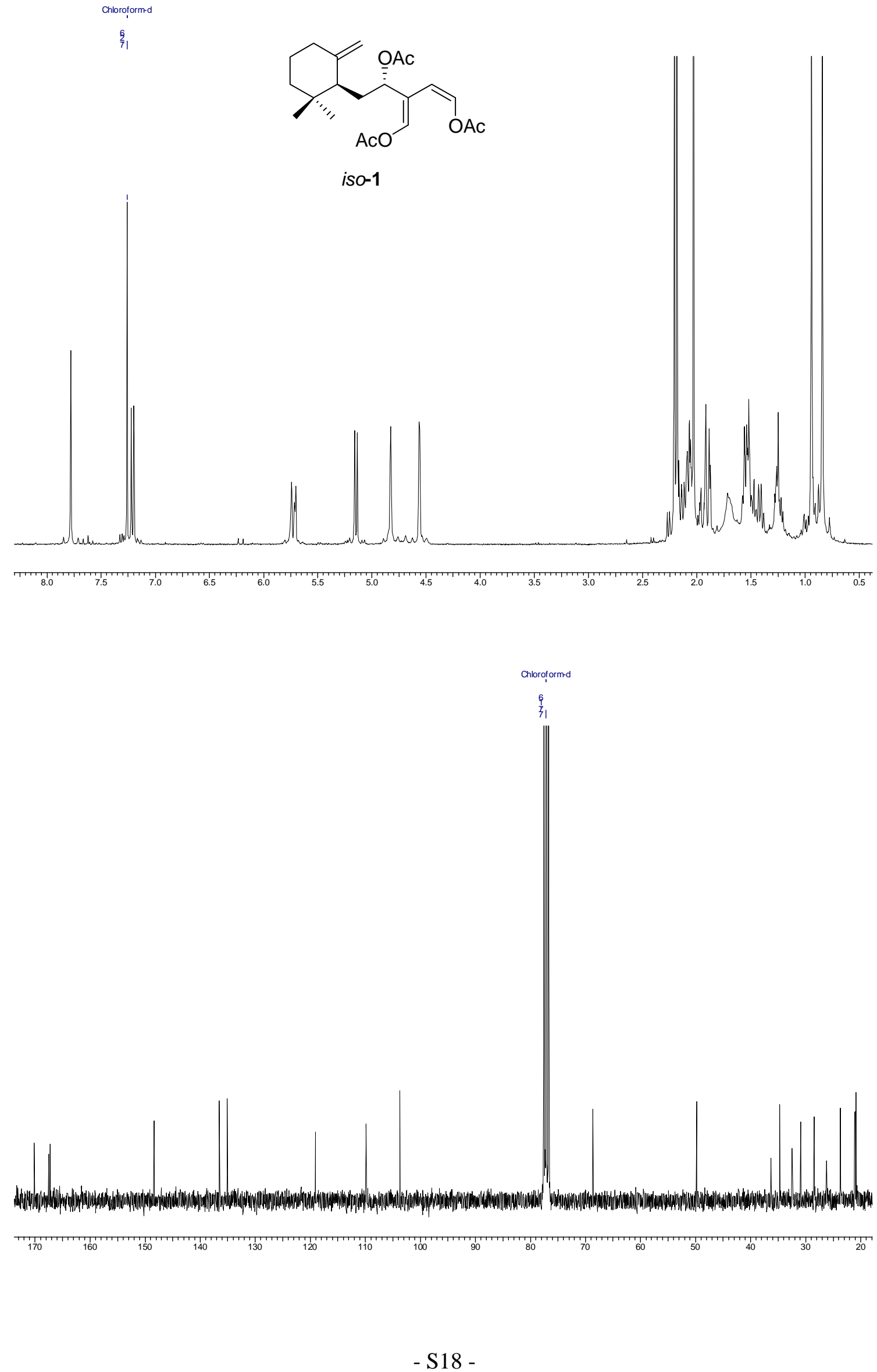